\title{
Michael W. Neff, 25 Years of Service to ASHS
}

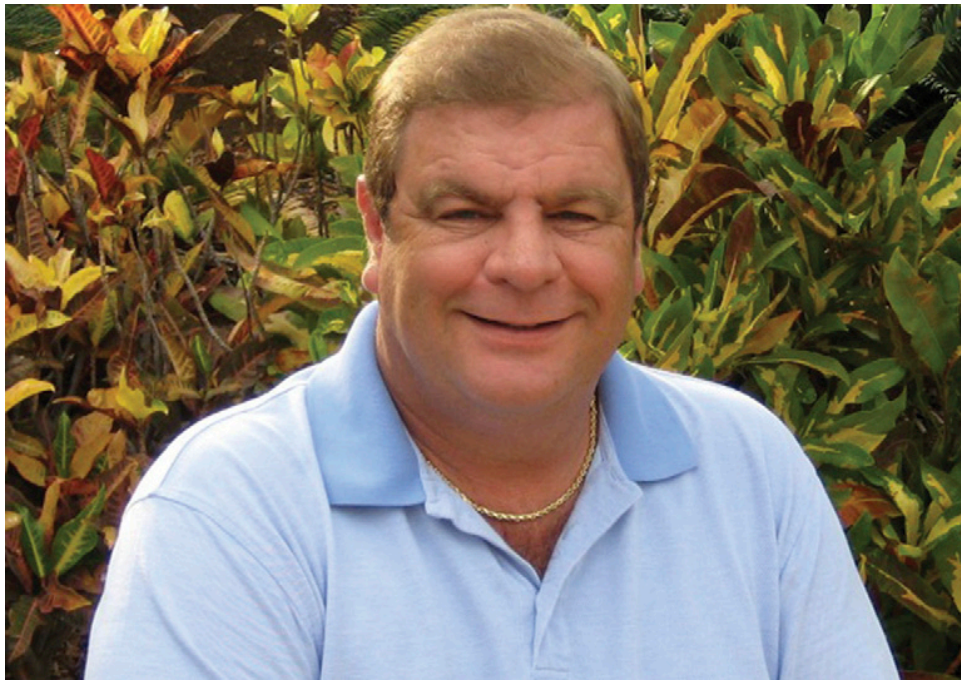

\section{Special HortScience Issue Honors Michael W. Neff}

This special HortScience edition honors Michael W. Neff, Executive Director of the American Society for Horticultural Science. Mike has very ably served ASHS with distinction for more than 25 years. There is not a more committed, loyal individual to ASHS than Mike. His leadership, organizational ability, and people-skills have served us well through thick and thin

Mike came to ASHS in Dec. 1985 as a strapping young Hoosier (land of corn, basketball, Michael Jackson, James Dean, John Dillinger, long drives, insane weather, racing, and a few rednecks). He spent summers working on his grandparents' farm in Indiana, which was family owned for more than a century. He was hired as the ASHS Production Editor - which seemed a good fit with his editing and production experience, a journalism degree from Ohio University, and his Ag experience. Both ASHS and Mike have evolved tremendously since then!

Mike's leadership has been paramount in guiding ASHS during a time when the landgrant system is and will continue to be severely challenged. His management style, humor, wit, friendliness, intelligence, competence, enthusiasm, and ability to read personalities, while maintaining an outward sea of calm have been critical in helping to set the tone and move ASHS forward. Having worked closely with Mike for the past seven years in developing the ASHS-Certified Horticulturist program, I have witnessed his deftness and skills in nudging and pushing ASHS forward to adapt to the new ventures needed to keep ASHS strong and relevant. His leadership style shows no ego - and in the mode of Ben Franklin: If one wants to accomplish something important, don't try and take credit for it.

ASHS first and foremost is a publishing house - it's our bread and butter that largely finances the organization. Mike has been very adept and technologically savvy in embracing the new electronic media age and helping ASHS adapt to the web and the rapidly changing world of publishing. That challenge continues today!

Mike's involvement with ASHS has also been a family affair. His wife, Marlenia, has been a very active partner in helping Mike with ASHS, along with his daughters, Victoria and Veronica. And Mike walks the talk: his daughter, Torie, just completed her first year in Horticulture at Virginia Tech.

The accolades that follow about Mike are from former and current ASHS leadership, as testament to his contributions to ASHS. And if you ever have the opportunity to visit Mike at ASHS Headquarters, make sure he takes you for a ride in his classic 1972 Lincoln Mark IV. While it only gets around $6 \mathrm{mpg}$, he now knows how to turn off the horn!

So thanks, Mike, for all that you do for ASHS and for Horticulture!

Fred T. Davies Texas A\&M University

\section{Mike and Me}

I really can't say how I met Mike. We've known each other a long time. I think the first time we actually met may have been at an ASHS conference, no surprise there! I was talking with Skip McAfee about something and I heard a voice say "Oh, you're Mary Albrecht!" with a quick follow-up with "not that I meant anything by that!" I must have given him one of my "I was born in New York, so don't mess with me" looks.

The thing about Mike is that he lives and breathes ASHS. He has been with the Society through the really good times and through the lows. He is always talking about how we are a volunteer organization. While that is true, we wouldn't be in the strong position we're in without Mike's vision for where we can go. $\mathrm{He}$ focuses on what is best for the membership, since the membership is the Society. He is willing to take "risks" once a risk-analysis - cost/ benefits analysis is done to make sure we've asked the right questions and sought the best counsel. Since he became Executive Director, there have been many changes in how ASHS functions as a professional, scientific society. These changes are a combination of the vision of ASHS members and leaders and the ability of Mike to bring the right people together to get the work of the Society accomplished.

What many people don't realize is that besides Mike, we also have Marlenia, his wife, working on behalf of the membership. She's been with him the whole time and helping out at annual conferences. Most people have met her at the registration desk or seen her taking photos during the annual business meeting or awards program. She's a big part of his success.

Of course, I can still hear the mischief in Mike's voice telling a story of a mutual acquaintance who was arrested for impersonating a police officer and having some unique items in the trunk of his car. Then there was the time he was driving some ASHS board members in his '72 Lincoln Mark IV when the horn wouldn't stop blaring until he disconnected the wire. But I won't go there; why embarrass him all over again!

Mike, thanks for your dedicated service these past 25 years and thanks for being someone I can count as one of my friends.

Mary Lewnes Albrecht University of Tennessee ASHS Archivist

When Mike began with ASHS, Ronald Reagan was President, Mikhail Gorbachev was the leader of the Soviet Union (it was still in existence), DNA was used for the first time in a criminal case, Top Gun was the number one movie in the United States, and Coca-Cola changed its formula and released New Coke. Sometimes we take things for granted and it is not until we have changed that we realize the difference a single person can make. Mike has led us from a "paper world" to the electronic age with grace and comforting reassurance. His strong, thoughtful leadership has been instrumental in revitalizing membership in ASHS, reaffirming a commitment to horticulture education, and critical for moving ASHS from the past into the future. As incoming ASHS President, I am very relieved to know Mike is there for me at ASHS. I will depend on his knowledge and level-headedness as I face decisions. He is our top-gun, and I hope he stays with ASHS for another 25 years!

Paul Bosland New Mexico State University ASHS President-elect

I am not sure the first time I sat down and talked to Mike Neff, sometime in the mid to late 1980s, and I think it was at an ASHS An- 

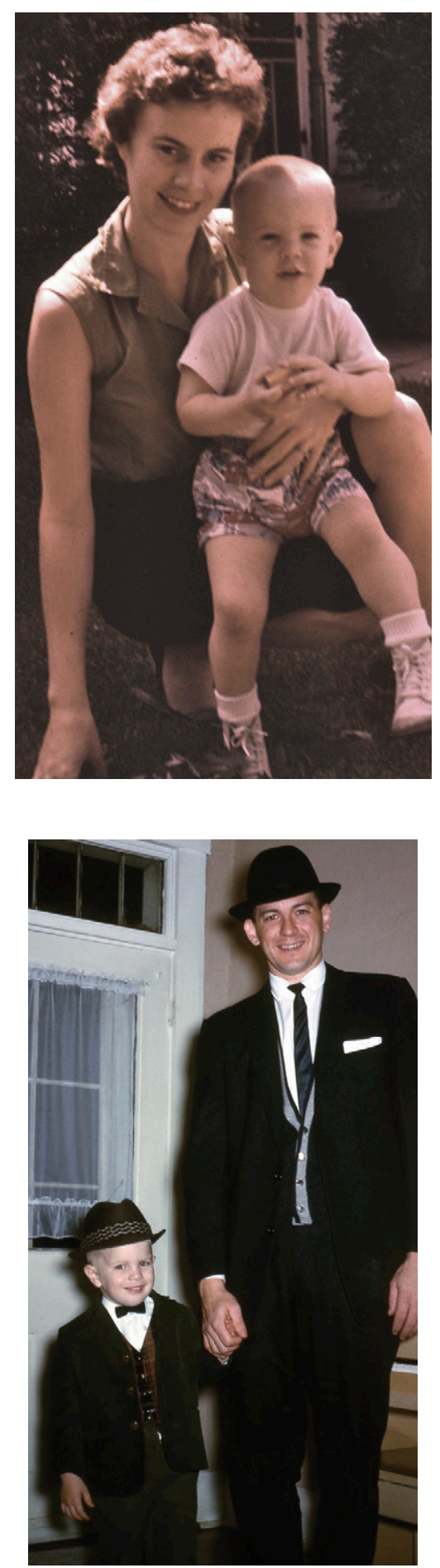

nual Conference. I don't remember the topic or topics we discussed, but I remember a few main items about Mike: he was a nice fellow, cared about my membership, involvement and interest in ASHS, and was willing to do about anything to help the Society. Here I write 25 years later, and I think the same things. A substantial amount of time passed and Mike and I have worked on numerous ASHS activities over the years. I have enjoyed every minute of my time with Mike Neff! Sometimes we were working on fun things, sometimes not so fun, but always Mike kept the Society's interests out front, shared wisdom, perspective and positive

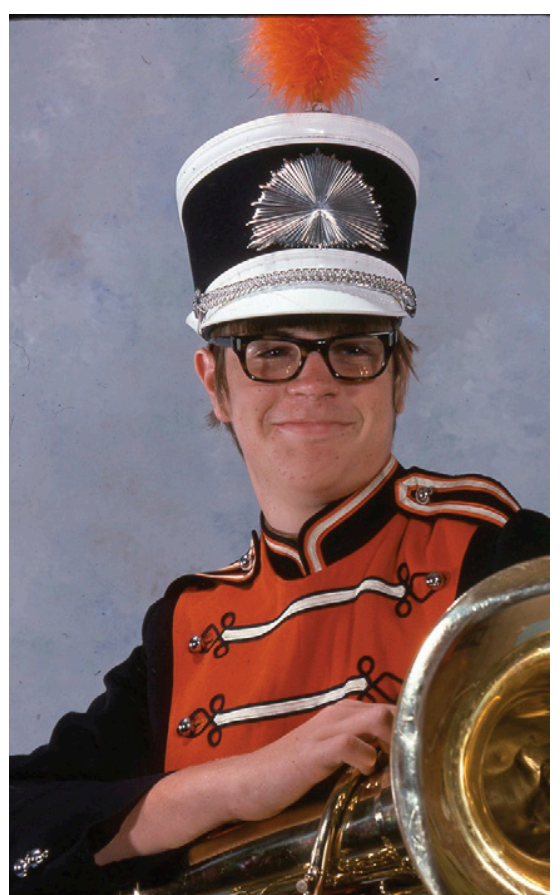

thoughts, and overall made ASHS an organization I was honored to be a member of. What more can one ask of an Executive Director? $\mathrm{He}$ enhanced the level of joy I experienced as an ASHS member and contributed to me looking forward to all activities I undertook in Society service during my career. Mike, you have my highest compliments and appreciation for a job well done!

John R. Clark

University of Arkansas

It's a good thing that Mike Neff doesn't know how great he is. I've worked closely with this soft-spoken, unpretentious ex-Hoosier for nearly 20 years. ASHS has changed a great deal over the past two decades, and from my perspective many of the benefits and attributes that members now enjoy can be traced to Mike's initiative and leadership.

On a personal level, I most value Mike's intelligence, competence, and unending sense of humor. He has been a calming influence, a stabilizing force, and has guided ASHS with the perspective of a wise elder. Mike is without question the best manager I have ever had. Often my working life as a commercial plant breeder seemed like one long Dilbert cartoon. I will be forever grateful that Mike bears no resemblance whatsoever to the Pointy-Haired Boss.

Neal E. De Vos

De Vos \& Associates Editor in Chief, ASHS Journal \& HortTechnology

I remember 25 years ago when ASHS hired Mike Neff, an enthusiastic, young journalism graduate, to manage our journals. Mike was dedicated to the job when hired and quickly become devoted to ASHS and the members and potential members. Mike's investment of 25 years has significantly impacted ASHS and he remains enthusiastic for horticulture and ASHS.

I specifically highlight three important attributes of his contributions to ASHS: leadership, management and personal relationships. As Executive Director, he has displayed leadership skills and knowledge of the role of professional associations in science in advancing our journals and the visibility of horticulture in DC and among other science-based societies. His recommendations to the Board about direction, focus, policies and procedures have been invaluable.

ASHS is functioning very efficiently because of Mike's attention to the details in managing the operations. He has hired an excellent staff and formed an effective team at headquarters. In particular, it is amazing how the time required for review and publication of manuscripts in our journals has been reduced. In recent years his management and recommendations have reduced our facility costs and number of full-time employees and resulted in outsourcing selected operations that can be done more efficiently by others.

Building genuine personal relationships with members is a hallmark of Mike's 25 years at ASHS. This comes naturally for him but I think he knows most members by name and knows something about most of our careers.

Personally, I have enjoyed our interactions over the years and particularly as I have served on the Board. He is a tremendous asset to ASHS and a friend. Thanks!

Dewayne Ingram University of Kentucky ASHS President, 2011-2012

\section{Ode to Mike Neff}

Congratulations Mike, I can now die and go to heaven,

Knowing you slaved for ASHS since 1987.

You started out with Cecil, and then went on with McAfee,

You even did your little bit with our friend Emely.

You came from Indiana you were always a straight shooter,

You started doing all our pubs and introduced us to computer.

When we were down and out and dying on the vine,

You found some new solutions, an efficient paradigm.

So Mike we offer our best wishes and thanks for what you've done,

We are really quite elated we are happy - everyone.

You know we need a leader, we all struggle to survive,

So we hope that you'll stay ED for another twenty-five!

Jules Janick Purdue University 


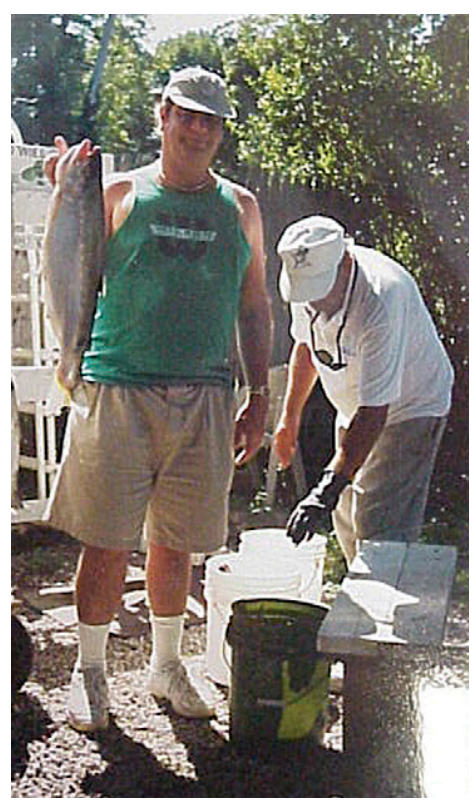

There are not enough words or space in this commemorative edition of HortScience to adequately express my sincere appreciation for all that my good friend and colleague Mike Neff has done for the American Society for Horticultural Science over his long and productive tenure in many different roles and positions. Mike is a true professional who has helped guide the society through some uncharted waters and I have always sought his wise counsel and advice. He always permitted me wide latitude in preparing outfits and entertainment for various social events at the Annual Meetings (although, I must admit he did roll his eyes several times) and I always enjoyed singing his favorite song "They Call the Wind Maria" from the musical Paint Your Wagon. Mike was always amazed at how my friends (I won't name them) always had large suitcases and boxes of educational materials destined for the meeting.

I remember one particular instance when we were going to a Board dinner on the outskirts of Washington, DC, and I believe it was in one of Mike's huge Lincoln Town cars that he keeps at the house. Now, I was really impressed to be riding with Mike and several other dignitaries in a large Lincoln Town car. Mike was handling the car through the traffic with his usual aplomb when all of a sudden the horn comes on and is blaring away. Mike is trying everything he knows to shut the horn off. Of course going through Washington, DC, in a Lincoln Town car is one thing but to be going through with the horn blaring away is entirely another matter. Of course Mike was beside himself while the rest of us in the car were howling with laughter.

We never let Mike live that one down. We laughed about that for years and always busted Mike's chops whenever he got behind the wheel to drive anywhere.

Mike my dear friend, I am glad to be part of celebrating your wonderful career with ASHS

\section{Notes from the Archivist}

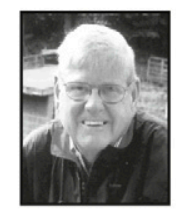

Donald N. Maynard

ASHS Archivist/Historian

Spotlight on:

Michael W. Neff, ASHS Executive Director
In the beginning....

"The ASHS Publications Department at Headquarters welcomes a new Production Editor; Michael Wayne Neff. A graduate of Ohio Univ., where he earned a BS in journalism and was a staff member of Athens magazine, Michael will assume his duties at ASHS on 2 Dec. 1985. For the past 2 years, he has been production editor for the Proceedings of the National Academy of Sciences. He also served as proofreader compositor for the Academy's Transportation Research Board. As ASHS Production Editor, Michael will be responsible for the production (including copy editing) and management of HortScience, the Journal, and ASHS Newsletter, as well as other publications currently under consideration."

ASHS Newsletter, November 1985 and to share just a few of my many memories with you and I look forward to making many more in the future. Your friend, Bill Lamont.

William J. Lamont Jr. Pennsylvania State University

\section{In Good Hands}

If the members are the heart and soul of ASHS, then surely Mike Neff is the hands, eyes, backbone, and legs of the organization! Without his forward-looking guidance and insightful management style, I fear we would have launched many forays into well-meaning, but often poorly thought-out ventures, that have arisen as a succession of Presidents and Boards have sought to put their stamps on the organization. Mike knows the members (each and every one!), he gathers information about their collective expectations and needs (the old-fashioned way, by asking them), and he counsels the Board on his findings without personal bias.

I've been attending ASHS meetings since 1969 , and can honestly not remember a time when Mike was not there-first as Cecil Blackwell's shadow and then as a stabilizing influence during some rough times when we were told that we had to change our direction or die.

ASHS remains the world's premier forum for the exchange of scientific information about horticulture. Under Mike's guidance we embraced the Web, learned that publications could be reviewed and published in less than ONEYEAR without loss of quality or quantity, finally got serious about certification programs, and even determined that science can be shared in media other than the printed page.

The applied sciences, particularly the agricultural sciences, are in for some rough sledding as we adapt to the disciplinary shuffle that has been the byproduct of the downward spiral in state and federal funding to our universities. We will need to rely on Mike's strong shoulders and steady hands a great deal during the transition. ASHS is in good hands! Thanks, Mike, for all you do and the way you do it!

Dan Lineberger Texas A\&M University

Mike Neff has had a long, distinguished career with the American Society for Horticultural Science. He was first employed in 1985 as the Production Editor (see ASHS Newsletter, November 2005) for the Journal and HortScience. He became Publications Director in 1988 and Executive Director in 1997. So, Mike has had a long career with ASHS in increasingly important roles. The Society now publishes three journals of international quality and recognition. Mike, the Editors and the editorial staff are largely responsible for the exceptional quality of our journals. Horticulturists worldwide want to be cited in our journals.

The Society is in sound financial condition with a quality Headquarters staff and facilities that should make us all proud. Much of this is due to Mike's leadership.

Mike's style, I believe, is to lead from behind; i.e., he usually lets a discussion on some issue run its course before speaking. Then, if in agreement based on past Society experience he remains silent or offers experience on what happened previously when the Society tried a similar course of action. In other words, Mike is our institutional memory of what worked or, more importantly, what didn't work in the past and was unlikely to work now.

Mike is now our second longest serving Executive Director and my hope is that he will continue in that role for years to come.

Donald N. Maynard University of Florida 

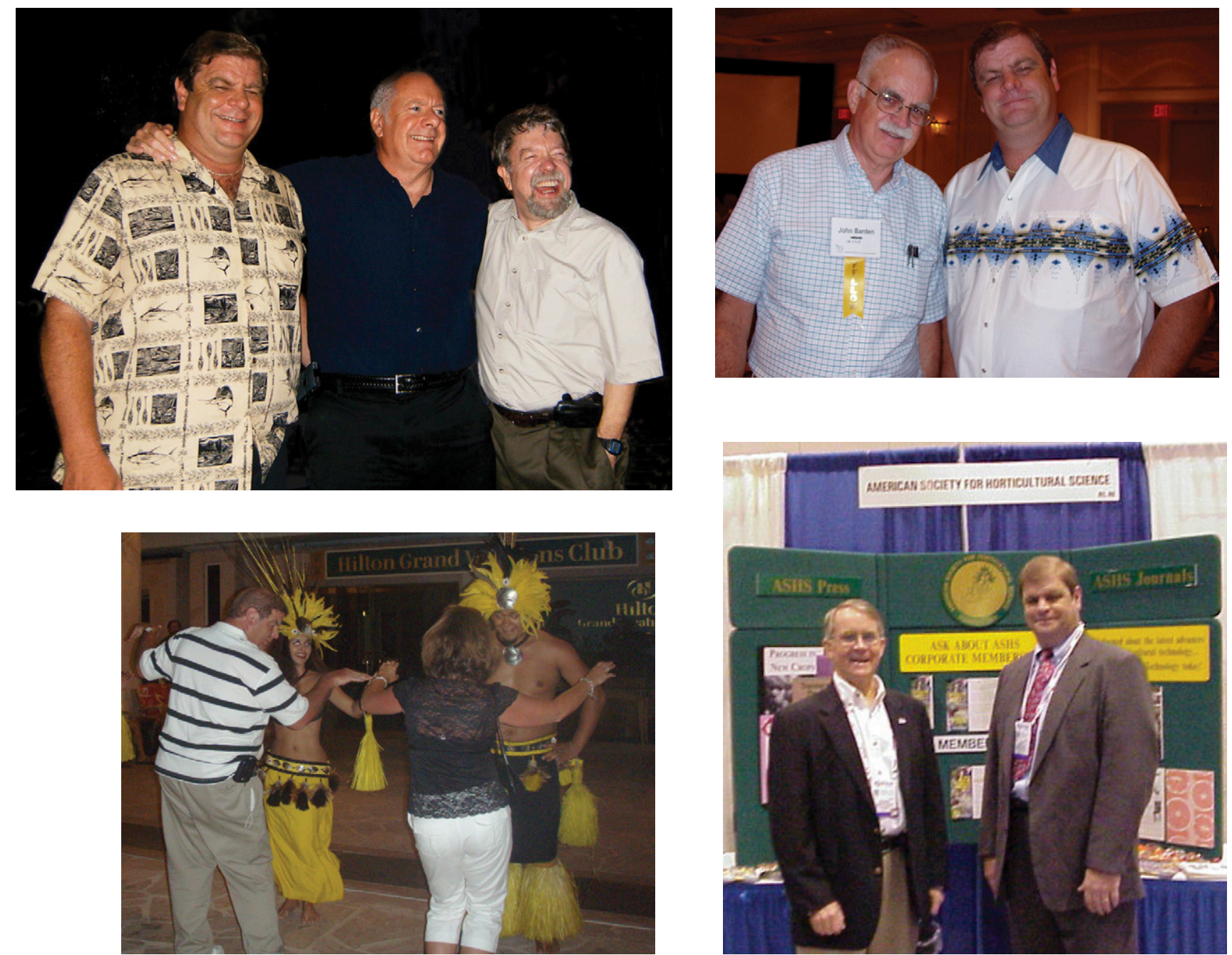

Twenty-five years? Nobody lasts for 25 years in anything these days! That guy Mike Neff must be king of the dinosaurs! Iremember Mike Neff back in the day, before he became Executive Director of ASHS, as a self-confident young ASHS Publications Director hailing from Indiana for then Executive Director Skip McAfee. Yikes! Are we that old? How does one survive that long as Executive Director of a major scientific society in this day and age with the slings and arrows that always come your way? Well, I will tell you how. You be Mike Neff, that's how! Mike embodies the spirit of progressiveness overlain with endless patience. To some, Mike looks like a big, glowering, intimidating guy, but underneath he is a compassionate teddy bear who cares deeply about his employees and customers.

Mike got it right from the start and stayed there. He always knew that the ASHS Headquarters staff must be there to provide essential services to its customer base, the ASHS membership! It never has been about Mike, and it never has been easy, but he has hung in there weathering a few storms and many successes. Mike has been an unselfish, unswerving executive leader of the ASHS organization lo these many years because he believes in horticulture and likes horticulturists, even those who take Headquarters to task because they didn't like where a conference was held, where it wasn't held, when it was held, how much it cost, which sessions conflicted with other sessions, etc. etc. etc. Mike always nods dutifully, does due diligence by taking all member concerns to the Board of Directors, and goes with the flow of Board decisions for the good of the many rather than the one, or the few. I recall when economic times were tough that Mike would push the Board for cost-of-living raises for his staff but would refuse to request a raise for himself. Although dreading it, he nevertheless made the hard decisions regarding staff as needed, and the result has been ever-improving, more efficient service to the ASHS membership with leaner and leaner Headquarters staff (numbers).

A great thing that Mike has done in recent years as academic professionals nationwide have been re-evaluating membership in scientific societies is to position ASHS to be a modern publishing and electronic communications venue. Mike constantly evaluates where electronic communications are at, where they are going, and works hard identifying expertise and technologies that will keep ASHS competitive at the forefront of scientific communications and publishing. ASHS has been most fortunate having an Executive Director the caliber of Mike Neff for the past 25+ years. Mike keeps himself relevant by thoughtfully evaluating where the Society is at and where it needs to go, not just for survival, but thrival! Mike Neff is a highly evolved dinosaur at the very top of the horticultural food chain! Best wishes, Mike, on this significant milestone with ASHS!

Cary A. Mitchell Purdue University

\section{Twenty-three Years of Friendship}

I have known Mike Neff since 1989, when he came to Tucson to help us in the planning of the 87th ASHS Annual Conference. Mike was working on ASHS publications and was given the task of getting all of the abstracts into the Annual Meeting Program. At this time that meant having the abstracts typed on a special form, within certain boundaries, photographed, sent to a printer, and finally mailed to the 

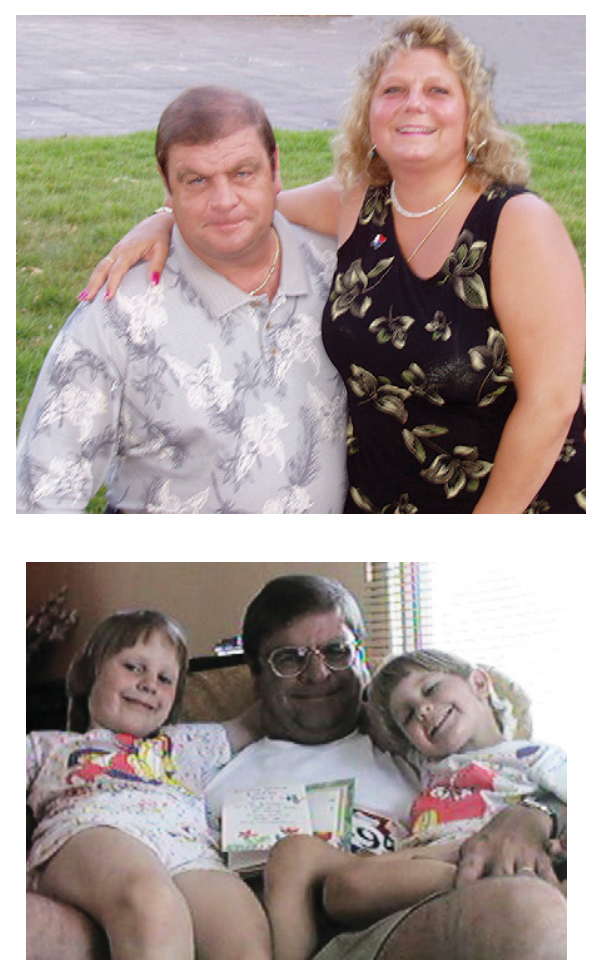

membership. I found Mike to be intelligent, interesting and talented, with a great deal of common sense, and a good sense of humor, but around us he seemed fairly quiet. I still agree with all of these traits, except the quiet part!

I truly believe that ASHS remains strong and relevant today because of Mike's unceasing work. Through his leadership Mike has made the management of ASHS more effective and efficient, he has kept our member benefits strong, increased our outreach, and improved our financial status. This was all done during times when many similar societies struggled, and the world around us, our membership, and the practice and teaching of horticulture all changed significantly. Mike accomplished this with his easy communication style and encyclopedic knowledge of ASHS, while working with many different Boards of Directors (essentially a new one every year).

On a personal level, I consider Mike one of my best friends, and I look forward to our getting together two or three times a year. As well as the traits I mentioned above, I now see Mike as a tremendously kind, sensitive, loyal, and caring person. Of course after 23 years, we have information about each other and experiences that give us a détente-type relationship. Mike does need to know, however, that no amount of alcohol at an ASHS meeting will get this information out of me (that is a challenge, so who is going to step-up), but I am sure he remembers (or maybe not) the 1997 March Madness meeting and Salt Lake City! All kidding aside, Mike really got me involved in ASHS at all levels, and I thank him for that, and Mike I thank you for your friendship, which I value greatly.

Dennis T. Ray University of Arizona

\section{Thanks from the Southern Region ASHS}

Under Mike's guidance, the American Society for Horticultural Science has made dramatic transformations to remain current in the publishing business and fiscally stable as a scientific organization, all without sacrificing its core vision and mission. Mike had a similar effect on the Southern Region of the American Society for Horticultural Science (SRASHS). His assistance allowed the SRASHS to move from a pay by check or cash and snail mail model to an online system for dues collection, registration for annual meetings and abstract publishing. His advice and counsel to the SRASHS Executive Committee on technical and legal issues has been invaluable. He has been a key influence as the SRASHS modernized and made the transition to the new millennium as the strongest and most viable region of ASHS. Mike, we thank you for your efforts over and above the call of duty and we appreciate you more than you will ever know.

Dave Reed

Texas A\&M University Secretary-Treasurer, Southern Region, ASHS

The first time that I met Mike he was an energetic editor who seemed to always be taking photos of the old people who were heavily involved in running the ASHS meeting that I was attending. It was one of my first experiences at such a meeting. Mike was, of course, much OLDER than me. He seemed to be quite friendly, and I was amazed at the energy level he displayed running around the meeting venue. I was also impressed that he seemed to be genuinely enjoying the meeting. Several years later I somehow became involved in hosting an ASHS meeting at our university (I think I was absent during the discussion at which the meeting location was decided). As Program Co-Chair, I had the opportunity to work closely with Mike on the technical program for the meeting. I discovered that he was not only enthusiastic about horticulture but was also eager to promote ASHS and the work done by its members. We had a conversation about the fact that ASHS needed to continually recruit new members to keep the society strong and its agenda relevant. Since he was much OLDER and worldlier than me, I took this advice to heart. I noticed that ASHS had a membership recruitment effort and that they even presented an award for the person who recruited the most new members. Even for a slow southern boy, that seemed like an easy way for a young person to get an award to include on his resume. So I began recruiting. I had a lot of recruits and thought that I would surely win the award that Mike said was a measure of how much I cared about ASHS. I was "totally bummed out" that one of those establishment OLD guys won the award. I tried again the next year. Lost again! I really started getting depressed. As John Clark would say, "Feeling lower than a snake's belly in a wagon rut."

Then Mike told me that there was a point system for the award and that recruiting a full

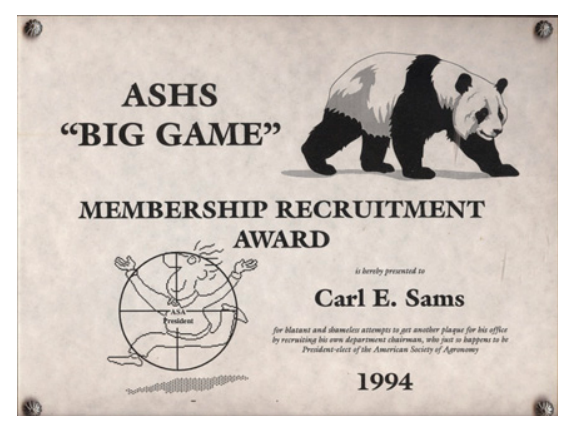

member was worth five points while recruiting a new graduate student was worth two points. Many of my recruits were graduate students. So I focused on bigger game. I applied my best sales tactics (used my BS and my PhD, "piled higher and deeper" skills). I recruited three students and two faculty members. I also recruited the new President of the American Society of Agronomy (ASA). I was full of pride and knew I deserved the shiny award that had eluded me the previous two years. I sent Mike an email stating that if the recruitment of a faculty member was five points, surely the recruitment of the President of another society had to be worth 50 points. I waited but did not hear anything back about my suggestion for more than a week. I then received an envelope in the mail. The outside of the envelope was marked "ASHS Recruitment Award." (It also said congratulations on recruiting the ASA president; that was quite a feat.) At last I had won the highly coveted award! Then I read the plaque!

I gained a friend forever! Today, that plaque is proudly displayed in my office. Mike, for your dedication to ASHS, your sincere interest in Horticulture as a profession, your efforts to make ASHS membership a great experience for everyone involved and, above all, for your sense of humor while doing it all, Thanks!! Hope we have you around another 25 years!

Carl Sams

University of Tennessee

\section{Mr. ASHS, Mike Neff, the "Can Do" Man}

Mike Neff joined ASHS in the late 1980s ... handling our publications during the beginning period of our most dramatic changes. We knew about his superb skills at editing quality materials ... and he quickly learned about the diverse business of horticultural science. Mike also learned about the diverse personalities of horticulturists! His secret to success was his unique ability to deal effectively and diplomatically with the entire range of horticulturists.

Along the way, Mike had the experiences of working with Cecil, Skip ... and Chuck, not to mention an interesting array of Boards of Directors, Editors, Finance Officers, etc. And then there were the Alexandria address changes along the way (at least he didn't have to endure a move back to St. Joseph, Michigan ... or to several of the other exotic options that were variously considered over the past couple of decades). Mike Neff matured well along 

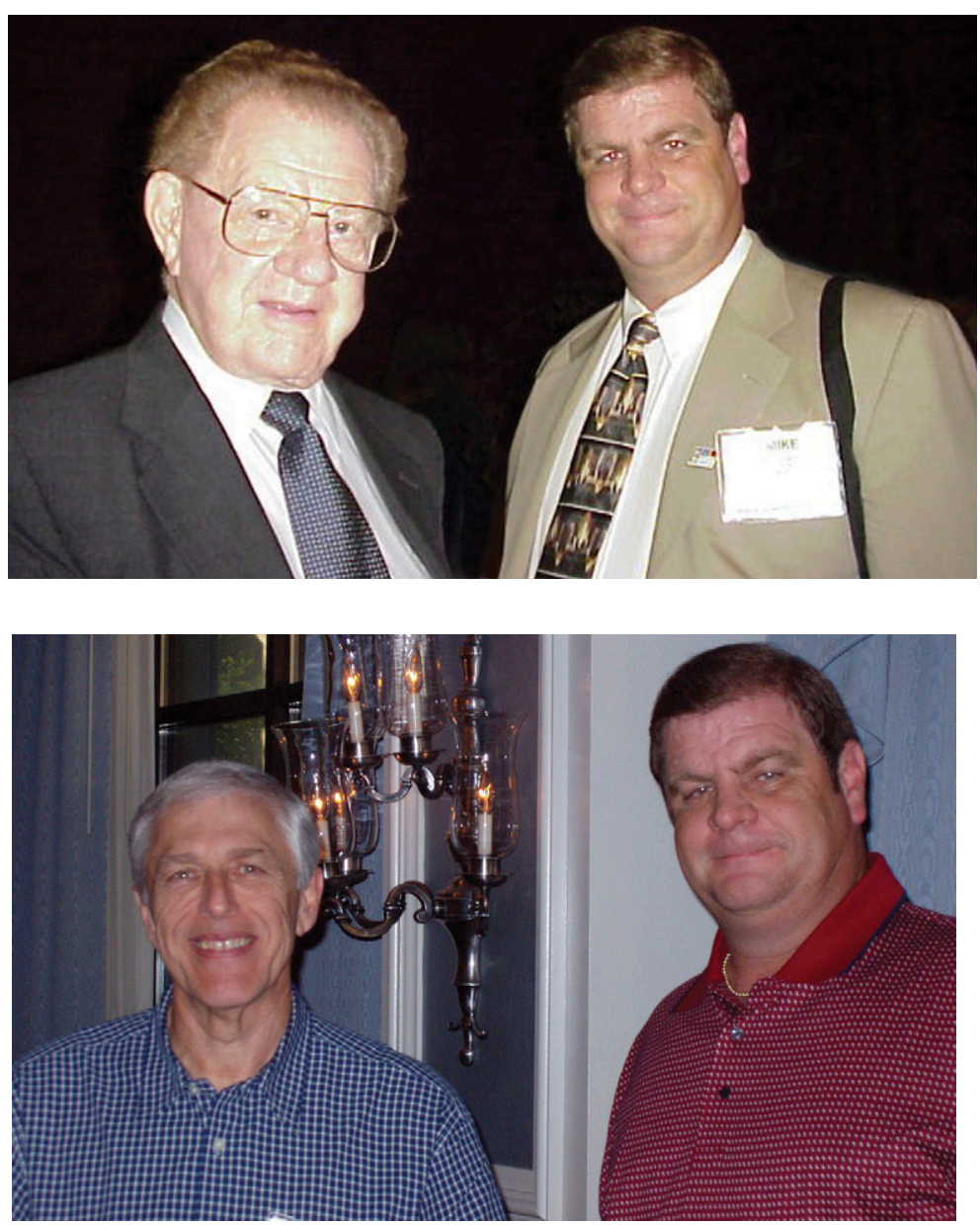

with the Society over the last quarter of its interesting first century of global horticultural leadership. He endured and survived multiple interesting relationships ... both internally and with other organizations. Lessons were learned via challenges of collaborations with ISHS, CAST, ISTH ... etc., etc., etc.

Those of us who have worked closely with ASHS over our professional lifetimes remember well these flows of leadership, management styles and technology advancements ... all managed in one way or another by our friend and Executive Director, Mike Neff. Personally, I debated long and hard whether or not to accept the nomination to be on the ballot for president of ASHS. In the process, I expressed my concerns to Mike about the many challenges of the multiple ASHS management issues with which I would have to deal if I were to be elected president. In classic Mike style, he simply assured me that he and his Headquarters staff really did all the work ... and again he was mostly right.

Mike has been able to resolve a comprehen- sive array of delicate issues by always being straightforward, frank, honest and consistent. He would deny it, but we all have learned to rely on Mike's wisdom. We have also appreciated Mike's creativeness and "can do" attitude accompanied by his uncanny skills at finding the right solution to every (well, at least most) situations. His sense of humor and ability to read personalities and appear to always have everything under control have combined to make him the right man to serve as our Executive Director over the past 25 years ... and for at least the next 25 years.

While we honor his loyal and generous service to ASHS, we really ought to be presenting Mike Neff with a breastplate full of medals commemorating his loyalty, dedication and survival of multiple "campaigns." Our future is bright because of Mike and Marlenia Neff ... it really has been a family affair, including Victoria and Veronica.

L. George Wilson North Carolina State University

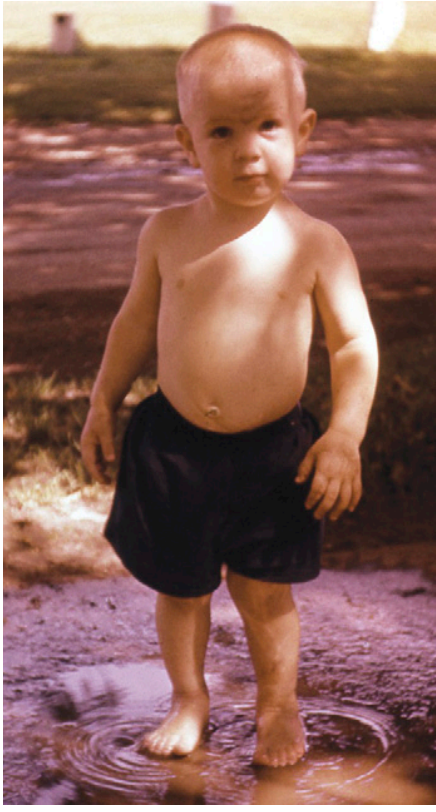

Michael Neff as I watched him grow up ...

Mr. ASHS, a.k.a. Mike Neff, came to Alexandria, Virginia, and ASHS headquarters in 1985. Mike is an energetic, highly charged and most absurdly very pushy guy as he knocked out three ASHS Executive Directors, Cecil, Skip, and Chuck, in order to take their jobs! He also "ran through" 25-plus ASHS Presidents and never could decide where ASHS headquarters should be located with three moves. Apparently nothing can make him happy! I was most impressed with Mike when I first met him because although he knew nothing about horticulture, he was always willing to learn. In those early days he would always be running postharvest storage studies in his office with his old lunches. Sometimes he could transform his old lunch into something very different looking and smelling in only a few months! My favorite is that he goes to bed about 6:30 pm at ASHS meetings, so Marlenia can go and have fun with the youthful members such as myself.

Although all of what was just written is true, I firmly believe that ASHS would not be what it is today without Mike Neff. He has dedicated his life, career, and soul to the organization. He has made ASHS a better Society regardless of how tough the times were and how changed the census and demographics of the members were. Simply put, ASHS would not be ASHS without Mike Neff.

Dan Cantliffe University of Florida 